\title{
REGULATIONS FOR THE PRESCRIPTION OF FOOTWEAR AS MEDICAL DEVICE
}

\section{DANIEL PETCU*, VIORICA ROŞCULET}

INCDTP - Division: Leather and Footwear Research Institute, 93 Ion Minulescu St., Bucharest, Romania, email: crispinian.ro@ gmail.com, icpi@icpi.ro

Received: 27.02 .2017

Accepted: 17.03.2017

https://doi.org/10.24264/Ifj.17.1.8

REGULATIONS FOR THE PRESCRIPTION OF FOOTWEAR AS MEDICAL DEVICE

ABSTRACT. Orthopedic footwear is part of the category of medical devices used in the conservative treatment of foot and lower limbs pathomechanics. For the custom-made medical device the manufacturer has to perform the design based on the prescription of a duly qualified medical practitioner that sets the specific design characteristics of the device. Quality management standards in the field of medical devices govern the entire process (or parts thereof) from design and development to delivery and provide technical support for their implementation. In this respect, the prescription is constituted as an input, respectively an essential requirement of the design process and must be complete and unambiguous. This paper aims to analyse aspects of medical prescription as an essential requirement of the design and manufacturing process of custom-made orthopedic footwear.

KEY WORDS: orthopedic footwear, medical device, prescription, quality management

\section{REGLEMENTAREA ACTIVITĂȚILOR LEGATE DE PRESCRIPȚIA ÎNCĂLȚĂMINTEI CA DISPOZITIV MEDICAL}

REZUMAT. Încălțămintea ortopedică intră în categoria dispozitivelor medicale utilizate în tratamentul conservator al patologiilor de natură mecanică ale piciorului și membrelor inferioare. În cazul dispozitivului medical fabricat la comandă, producătorul trebuie să realizeze proiectarea pe baza prescripției practicianului medical calificat în mod corespunzător prin care acesta stabilește caracteristicile specifice de proiectare ale dispozitivului. Standardele de management al calității în domeniul dispozitivelor medicale definesc condițiile de calitate care guvernează întregul proces (sau părți ale acestuia) pornind de la proiectare și dezvoltare până la livrare și acordarea suportului tehnic pentru implementarea acestora. În acest sens, prescripția medicală se constituie ca o intrare („input”), respectiv o cerință esențială a procesului de proiectare și trebuie să fie completă și lipsită de ambiguitate. Prezenta lucrare își propune să analizeze aspecte ale prescripției medicale ca o cerință esențială a procesului de proiectare și realizare a încălțămintei ortopedice fabricate la comandă.

CUVINTE CHEIE: încălțăminte ortopedică, dispozitiv medical, prescripție, managementul calității

\section{DES ACTIVITÉS RÉGLEMENTAIRES POUR LA PRESCRIPTION DES CHAUSSURES COMME DISPOSITIF MÉDICAL}

RÉSUMÉ. Les chaussures orthopédiques entrent dans la catégorie des dispositifs médicaux utilisés dans le traitement conservateur des pathologies de nature mécanique du pied et des membres inférieurs. Dans le cas du dispositif médical fait sur mesure, le fabricant doit effectuer la conception à partir de la prescription d'un médecin dûment qualifié qui définit les caractéristiques de conception spécifiques du dispositif. Les normes pour la gestion de la qualité dans le domaine des dispositifs médicaux définissent les exigences de qualité qui régissent l'ensemble du processus (ou ses parties) à partir de la conception et du développement et jusqu'à la livraison y compris fournir un soutien technique pour la mise en œuvre des produits. À cet égard, la prescription médicale est considérée comme une entrée ("input") et une exigence essentielle du processus de conception et doit être complète et sans ambiguïté. Cet article vise à analyser les aspects de la prescription comme une exigence essentielle de la conception et la mise en œuvre des chaussures orthopédiques sur mesure. MOTS-CLÉS: chaussures orthopédiques, dispositifs médicaux, prescription, gestion de la qualité

\section{INTRODUCTION}

The World Health Organization (WHO), includes therapeutic footwear (for diabetes, neuropathy and orthopedic) together with the orthoses for lower limb in Priority Assistive Products List (LPA) [1]. According to EN ISO 9999: 2016: "Assistive products for persons with disability - Classification and terminology" [2], orthopedic footwear together with foot orthoses are included in the Class "orthotics and prosthetics", subclass "orthotics", defined as devices applied on the surface of the considered anatomical segment with a purpose to change the structural and functional characteristics of the neuro-musculoskeletal system [3]. EN ISO 9999: 2016 defines three categories of orthopedic footwear, namely: "off-the-shelf", "customized", and "custom-made/bespoke". According to existing legal regulations, medical devices (prostheses, orthoses) are used in a specialised activity "in order to overcome some organic or physiological deficiencies" [4]. Activities related to the manufacture of medical devices are supported by national insurance systems; in Romania the following categories

\footnotetext{
* Correspondence to: Daniel PETCU, INCDTP - Division: Leather and Footwear Research Institute, 93 lon Minulescu St., Bucharest, Romania, email: crispinian.ro@gmail.com, icpi@icpi.ro
} 
of devices are found, according to the purpose of this work [5]: foot orthoses, arch supports, orthopedic footwear (boots and shoes with the following types: deformities, with spring, amputations of metatarsus and phalanges, lower limb discrepancy).

Existing regulations on medical devices establish the following definitions [6, 7]:

- "medical device - any instrument, apparatus, appliance, software, material or other article, whether used alone or in combination, including the software intended by its manufacturer to be used specifically for diagnostic and/or therapeutic purposes and necessary for its proper application, intended by the manufacturer to be used for human being for the purpose of:

a) diagnosis, prevention, monitoring, treatment or alleviation of disease;

b) diagnosis, monitoring, treatment, alleviation of or compensation for an injury or handicap;

c) investigation, replacement or modification of the anatomy or of a physiological process";

- "custom-made device - any device specifically made in accordance with a duly qualified medical practitioner's written prescription which gives, under his responsibility, specific design characteristics and which is intended for the sole use of a particular patient. The above mentioned prescription may also be made out by any other person authorized by virtue of his professional qualifications to do so".

The process by which a custom-made medical device is introduced in the conservative treatment of foot pathomechanics must be governed both by the regulations specific to each country and the requirements of quality management systems standards such as EN ISO 9001: 2015 or ISO 13485: 2016. For the purposes of these standards, a process is defined as the activity starting from an "input" which is transformed into an "output". Analyzing the medical devices definitions mentioned above, we see that besides the "manufacturer", in the case of custom-made medical device a "qualified medical practitioner" or "any other person authorized by virtue of his professional qualifications" are added. It is worth noting that the standard EN ISO 13485: 2016 includes in the section "Terms and definitions" a definition for medical device but does not include one for "custom-made device" [8].

For the purpose of standard EN ISO 13485:2016 and "Global Harmonization Task Force"- GHTF/SG1/N055:2009 (developed by IMDRF-International Medical Device Regulators Forum), the manufacturer is an entity that has both the responsibility of design and/ or to manufacture the medical device with the intent to make it available for use, and to ensure compliance with applicable regulations except when the latter is in the duty of another entity in accordance with the existing laws $[8,9]$. In the same sense, the design and/ or manufacture process may also include, in addition to manufacturing, other activities such as "development of the specifications". It can be seen that in the case of the custommade device in the input data of the design process the prescription is determinant, being the responsibility of the medical practitioner or of any other person authorized by virtue of his professional qualifications that gives specific design characteristics. Thus, the prescription is considered as an input, respectively an essential requirement of the design process and it has to be in accordance with EN ISO 13485: 2016: complete, unambiguous, verifiable and validated [8].

\section{Medical Prescription Definition}

According to the Explanatory Dictionary of the Romanian Language and related with the medical act "prescription represents a recommendation given by the physician to a patient (through a recipe); recommendation for using a drug" [10]. In general terms, the prescription is an "obligation, disposition, provision" or a set of "written instructions including technical conditions to be followed in the design, verification or manufacturing of a technical system" [10]. According to Belknap, S. et al., "a prescription is a health-care program implemented by a physician or other qualified practitioner in the form of instructions that 
govern the plan of care for an individual patient" [11].

A complete description of the "prescription" concept is provided by the pharmacology field, the stages of the magistral preparation/drugs' prescribing process and the one of the custom-made medical devices could be considered similar. Thus, in the medicine field the prescription represents an instruction, respectively the mean of communication between the prescribing doctor and the pharmacist achieved through a written document [12].

Constitutive elements of the medical prescription and their definition may differ from country to country, there is not yet a unique standard [12] but basically, there are 7 elements [13-15]:

- "superscriptio" - contains the header,

- "inscriptio" - contains the patient data,

- "invocatio" - contains the abbreviation

(Rp or Rx) of the word "Recipe",

- "prescriptio" ("ordinatio" / "compositio")

- in the case of magistral drugs it contains data about the necessary ingredients to be used,

- "instructio" - contains information regarding the way of drugs' administration,

- "subscriptio" - contains instructions for the magistral drug preparation,

- "adnotatio" - contains information provided by the pharmacist (added auxiliary substances, date, price, and others).

Whichever format is used, the prescription must be unambiguous [12], as this is an essential requirement of the quality management standards for which the prescription is an input document for the medical device design [8].

\section{Practice of Medical Devices Prescription}

Medical devices based on a prescription may be used only under the guidance and instructions of an authorized specialist [14, 16]. Prescription differs from country to country both in terms of its content and of the eligible prescribers, depending on how the prescribing competencies of the medical specialities who have the responsibility for the foot pathomechanics treatment are defined. The problem of communication between the medical practitioner and the medical device provider represents a continuing preoccupation [17] and it is topical especially in the countries where specialized segments of medical devices field are not sufficiently developed [18, 19]. As far back as 1969 Henderson discusses the problem of foot orthoses prescription in the context where difficulties were noted for the eligible prescribers in order to be up to date with the evolutions in the field of medical devices design [17]. These difficulties are hindering the effective communication between medical and technical specialists leading to an implicit transfer of the medical practitioner responsibilities to the technical one in relation to the establishing of the specific design characteristics for the medical device.

From the prescription definition results that in the case of medical devices "prescriptio" must contain the name, the type and the specific design characteristics of the medical device, which, according to the custom-made device definition are the prescriber's responsibility and not the manufacturer's. The general template of the medical prescription presented in the legal rules of the medical devices from Romania [20] only includes the name and the type of the recommended medical device where, for example, in the case of orthopedic footwear the name may be "boots" or "shoes" while the device type is described as: "deformities", "amputations of metatarsus and phalanges" and "lower limb discrepancy". In the same way in which the pharmacist must prepare the magistral drugs according to the physician's prescription, the technical specialist in the field of custom-made orthopedic footwear (from allied health professions as: pedorthist, orthopaedic shoemaker meister, orthotist) have to manufacture the product according to specific design characteristics indicated by the prescriber. The World Health Organization (WHO) has developed a "Guide to Good Prescribing" for drugs which describe the implementation process of a medical treatment, as follows [21]:

1. definition of the patient problem,

2. specification of the therapeutic objective, 
3. verifying the adequacy of the treatment for a given patient's specific case,

4. writing a prescription - initiation of treatment,

5. informing the patient about the prescribed treatment,

6. monitoring the treatment.

Diagnosis, namely identification of the pathological condition [10] or defining the patient's problem [21] represents a preliminary stage of the prescription writing. The steps to be followed for the use of foot orthoses in the treatment are [22, 23]:

1. clinical evaluation,

2. writing prescription \& and conducting measurements,

3. orthosis fitting,

4. monitoring the evolution of the treatment.

A reference example in the nomination of the medical specialists with clearly defined competencies in the medical footwear prescription comes from Australia where the eligible prescribers are: physician in medical specialities as surgical ones (vascular surgery, orthopedics), physical and rehabilitation medicine, rheumatology, geriatrics, neurology, endocrinology; specialists in physiotherapy; specialists in occupational therapy; podiatrists; orthotists / prosthetists [24, 25]. It is worth noting that in the state of New South Wales in Australia the Certified pedorthists are considered eligible prescribers [25]. According to the Pedorthic Association of Canada (PAC), the Certified pedorthist develops the medical device prescription based on the referral received from the physicians, nurses or other medical practitioners. Orthoses prescription represents the detailed instructions on how to manufacture, containing information about the design parameters, materials, composition and production [26]. It is important to understand if the "prescription" as understood by PAC has the same meaning for insurers companies from Canada who reimburse for custom-made medical devices. It is also worth noting that in some countries a medical specialist who is not included in the list of eligible prescribers may be accredited on demand for this activity through a clearly defined process [24]. In the UK where pedorthics does not exist, footwear prescription is made by an orthotist being at least at the 6th qualification level ("Specialist/Senior Practitioner") according to professional classification in this field [27, 28]. This qualification level is obtained in the UK based on studies at an university level (higher education) unlike the situation from Romania where the qualification of orthotist-prosthetist technician is obtained through studies at the third level (secondary or post-secondary education) [29]. Unlike the situation in UK where footwear prescription is included explicitly in the orthotist's competencies, in Romania the occupational standard for the profession of orthotist-prosthetist technician makes no reference to orthopedic footwear [27-29].

WHO together with the International Society for Prosthetics and Orthotics (ISPO) define three categories (I, II, and III) of the specialists in the Orthotic \& Prosthetic field [19, 30, 31]:

- Category I: Prosthetist-Orthotist equivalent of a four-level training (higher education with a duration of 3-4 years),

- Category II: Orthopaedic Technologist - the equivalent of a three-level training (postsecondary school education with a duration of 3 years),

- Category III: Prosthetic/Orthotic Technician - the equivalent of a two-level training, qualification at the workplace. This category works only in the medical device manufacturing process under the guidance of specialists from the first two categories.

The WHO and ISPO documents show that in the Orthotic \& Prosthetic field, specialists must have a university level education in accordance with professional standards of Category I. In developing countries, in the absence of Category I, its attributions can be shared by specialists from Category II for which, according to the specific casuistry, there is the possibility to obtain the qualifications only in certain subfields such as prosthetics or orthotics for upper or lower limb [19]. According to ISPO documents Category I specialists have the professional expertise in the area of orthopedic footwear while professional Category II has competences only for footwear 
modification [30, 31]. The cited ISPO documents note that there are difficulties in establishing professional designations because of the particularities found from country to country. This is true for Romania also where it is obvious that the Occupational Standard for qualification of orthotist-prosthetist technician designates the specialized personnel according to ISPO Category II.

The medical literature is reviewing many prescription variables or specific design characteristics of the medical devices especially for foot orthoses. There is information regarding the preferences related to prescribing habits in specific geographical areas [32], studies regarding recommendations based on specialists consensus for the prescription variables for certain pathologies [33-35] or comparisons between medical devices made by different categories of specialists in relation to the treatment objective achievement [36]. In the context of the continuously developing medical devices field the question arises whether the eligible prescriber's competencies are up to date with this evolution. Also an important issue is mentioned concerning the transfer of responsibility from the prescribing specialist to the medical device manufacturer in the case of an incomplete prescription. In this context, since 1969 Henderson and Lamoreux, recognized specialists for their involvement in the study and development of UCBL foot orthosis type (University of California Biomechanics Laboratory), have proposed an approach to medical devices prescription according to the following steps [17]:

1. establishing of the "diagnosis" by the physician,

2. establishing by the physician of the "medical objectives" for using the devices, based on the information provided by other members of the interdisciplinary team,

3. establishing "functional descriptions" by the physician where the "medical objectives" are transposed into the medical device objectives,

4. developing a "treatment program" by the physician, based on the information provided by interdisciplinary team where necessary.

Under the procedure proposed above, the orthotist (or another specialist in medical devices designing field) establishes "specific design characteristics" and manufacture the device following the objectives set for it. A good example of this can be considered the transposition in terms of the prescribing procedure described by Henderson and Lamoreux of the therapeutic footwear optimizing process for patients with diabetic neuropathy described by Sicco A. Bus and others [37]. Thus for therapeutic footwear prescribed by a specialist in physical and rehabilitation medicine the following elements can be formulated:

- "medical objective": reducing the risk of ulceration,

- "functional description": decreasing the pressures in the at risk areas from the plantar surface of the foot $25 \%$ below initial value (criterion no. 1) or below $200 \mathrm{kPa}$ (criterion no. 2). Areas "at risk" were defined as those areas where peak pressure measured with an in-shoe measuring system are more than $200 \mathrm{kPa}$.

Based on this functional description the specialist in orthopedic footwear (the pedorthist) with a minimum of 4 years' experience in the treatment of diabetic foot has made footwear modifications, respectively an "optimization" of specific design characteristics so as to meet one of the two criteria established in the "functional description". The authors report that footwear "optimization" lasted 53 minutes on average. Optimization algorithm of therapeutic footwear meets the requirements of quality management standards through appropriate process documentation.

An ISPO report on education in the Orthotic \& Prosthetic field at European level shows that for example in Belgium the medical devices prescription by a physician is an "open prescription", containing only the "desired orthopedic effect" which can be assimilated with the "medical objective" described above. The same document shows the existence of different practices regarding prescription rights of Prosthetist-Orthotists stressing the importance of differentiating "medical prescription" (as an attribute of the medical practitioner) by the "technical prescription" (as an attribute of Prosthetist-Orthotists of Category I) [38]. A good 
example of establishing a medical objective and a functional description as part of the prescribing of a medical device comes from the podiatry field from USA through the development of a guidelines document regarding the prescription of foot orthoses [39]. According to the USA Medicare insurance system footwear made from the positive mold of the patient's foot ("custommolded") may be prescribed by a podiatrist or other qualified doctor [40]. It is obvious that where there is duly qualification [6], the medical practitioner may indicate the device's technical specifications. The orthotist/ pedorthist may participate together with the physician to assess the effectiveness of the device obtained from this process. It is worth noting that both elements of this way of prescription and the need to develop it on the basis of team activities for complex devices are found in current practice of some countries [25].

\section{CONCLUSIONS}

The prescription problem is a sensitive issue especially in countries where specialized areas of foot conservative treatment based on specific medical devices such as podiatry or pedorthics are not developed. Through the lack of the "specific design characteristics" from custom-made medical device prescription, a transfer of responsibility from the eligible prescriber to the manufacturer is realised.

Considering the fact that in the current clinical practice there are many situations where the prescription is limited only to the indication of the name and the type of the medical device, a solution to this problem could be the introduction of a regulation where based on the "diagnosis", "medical objectives" and "functional description" developed by the medical practitioner the technical specialist may establish the "specific design characteristics" in a technical prescription.

Open approach and finding practical solutions to the problem of medical devices prescription is the only solution through the responsibilities for conservative treatment of foot pathomechanics are properly shared among the members of the interdisciplinary team. Such a "win-win situation" approach can only be to the benefit of the specialists involved in the treatment and especially to the patient who has the right to benefit from an effective treatment.

\section{REFERENCES}

1. World Health Organisation, WHO, Priority Assistive Products List, 2016, http://www. who.int.

2. Assistive products for persons with disability - Classification and terminology, EN ISO 9999:2016, https://www.iso.org.

3. Prosthetics and orthotics -- Vocabulary -- Part 1: General terms for external limb prostheses and external orthoses, EN ISO 8549-1:1989, http:// www.iso.org.

4. Law no. 95/2006 on Healthcare Reform, Monitorul Oficial, no. 372/28 Apr. 2006.

5. The basic package - list of the medical devices for the ambulatory rehabilitation of some organic or functional impairments, 09 May 2014, http://www.cnas.ro.

6. GD no. 54/2009, 29 January 2009 on the conditions for the entry of medical devices on the market, Monitorul Oficial, no. 94/17 Feb. 2009.

7. Directive 2007/47/EC of the European Parliament and of the Council of 5 September 2007 amending Council Directive 90/385/ EEC on the approximation of the laws of the Member States relating to active implantable medical devices, Council Directive 93/42/EEC concerning medical devices and Directive 98/8/ EC concerning the placing of biocidal products on the market, Official Journal of the European Union, 21.9.2007, http://eur-lex.europa.eu.

8. Medical devices-Quality management systemsRequirements for regulatory purposes, Chapter 3, Terms and definitions, EN ISO 13485:2016, 2016, https://www.iso.org.

9. Definitions of the Terms Manufacturer, Authorised Representative, Distributor and Importer, Global Harmonization Task Force, 
GHTF/SG1/N055:2009, International Medical Device Regulators Forum (IMDRF), March 26, 2009, http://www.imdrf.org.

10. Explanatory Dictionary of the Romanian Language (second edition revised), Romanian Academy, "Iorgu Iordan" Linguistic Institute, Univers Enciclopedic Gold, 2009.

11. Belknap, S.M., Moore, H., Lanzotti, S.A., Yarnold, P.R., Getz, M., Deitrick, D.L., Peterson, A., Akeson, J., Maurer, T., Soltysik, R.C., Storm, G.A., Brooks, I., Application of Software Design Principles and Debugging Methods to an Analgesia Prescription Reduces Risk of Severe Injury From Medical Use of Opioids, Clin Pharmacol Ther, 2008, 84, 385-392, doi:10.1038/clpt.2008.24.

12. de Vries, T.P.G.M, Henning, R.H., Hogerzeil, H.V., Fresle, D.A., Guide to Good Prescribing - A Practical Manual, Chapter 9 - "Step 4: Write a Prescription", 66-71, World Health Organization, 1994, http://www.who.int/en.

13. Standard of professional qualification, Qualification: Medical pharmacy assistant, Level 3 advanced, Ministry of National Education, Bucharest, 2006, http://oldsite.edu. ro/index.php/articles/6572.

14. "Medical prescription" definition, https:// en.wikipedia.org/wiki/Medical_prescription.

15. Food \& Drug Administration, FDA-USA, Title 21 - Food and Drugs, Chapter I - FDA Department of Health and Human Services, Subchapter H-Medical Devices, https://www.fda.gov.

16. "Prescription" definition, http://medicaldictionary.thefreedictionary.com/prescription.

17. Henderson, W.H., Lamoreux, L.W., The Orthotic Prescription Derived from a Concept of Basic Orthotic Functions, Bull Prosthet Res, 1969, Spring, 89-96.

18. Petcu, D., Deselnicu, D., Guta, S.A., Berijan, G., Aspects Regarding the Development of the Medical Footwear Industry in Romania, Proceedings of the 4th ICAMS 2012, 27-29 September 2012, Bucharest, Romania, 365-370.

19. WHO, Guidelines for Training Personnel in Developing Countries for Prosthetics and
Orthotics Services, ISBN: 924159672, 2005, http://www.who.int/medical_devices.

20. "Medical prescription-recommendation on granting medical devices for the rehabilitation of some organic or functional impairments", Annex 39D from the Order no. 763/2016, http://www.cnas.ro.

21. de Vries, T.P.G.M, Henning, R.H., Hogerzeil, H.V., Fresle, D.A., Guide to Good Prescribing A Practical Manual, "Chapter 1 - The Process of Rational Treatment", 7-16, World Health Organization, 1994, http://www.who.int/en.

22. Petchell, A., Keenan, A.-M., Landorf, K., National Clinical Guidelines for Podiatric Foot Orthoses, Australas J Podiatr Med, 1998, 32, 97.

23. Australian Podiatry Council, Clinical Guidelines for orthotic therapy provided by podiatrists, Australian Podiatry Manual Supplement, May 1998.

24. Medical-grade Footwear - Eligible Prescribers, Queensland Government, Australia, https:// www.health.qld.gov.au/mass/prescribe/ footwear.

25. Prescribers, Enable NSW Health Support Services, New South Wales Government, Australia, http://www.enable.health.nsw.gov. au/home/prescribers.

26. Working Together: Healthcare Providers and Pedorthists, Pedorthic Association of Canada, http://www.pedorthic.ca/for-health-careproviders.

27. Scottish Diabetes Education Advisory Group, Orthotics Competency Framework for the Prevention, Treatment and Management of Diabetic Foot Disease, http://www. diabeteseducationscotland.org.uk.

28. Nicol, A., Career Framework Guide Prosthetics \& Orthotics, https://www.bapo.com.

29. Occupational Standard, Prosthetist/Orthotist Technician, 2008, http://www.cereas.info.

30. ISPO, Category I Professional-Prosthetist/ Orthotist, Orthopaedic Engineer, Orthopaedic Meister, Information Package, August 2007, http://www.ispoint.org/standards-guidelines. 
31. ISPO, Category II Professional-Orthopaedic Technologist, Information Package, May 2010, http://www.ispoint.org/standards-guidelines.

32. Landorf, K., Keenan, A.-M., Rushworth, R.L., Foot Orthosis Prescription Habits of Australian and New Zealand Podiatric Physicians, Am Podiatr Med Assoc, 2001, 91, 4, 174-183.

33. Banwell, H.A., Mackintosh, S., Thewlis, D., Landorf, K.B., Consensus-based Recommendations of Australian Podiatrists for the Prescription of Foot Orthoses for Symptomatic Flexible Pes Planus in Adults, $J$ Foot Ankle Res, 2014, 7, 49.

34. Hijmans, J.M., Geertzen, J.H.B., Development of Clinical Guidelines for the Prescription of Orthoses in Patients with neurological disorders in The Netherlands, Prosthet Orthot Int, April 2006, 30, 1, 35-43.

35. Munro, W., Orthotic Prescription Process for the Diabetic Foot, The Diabetic Foot, 2005, 8, 2.

36. Guldemond, N.A., Leffers, P., Schaper, N.C., Sanders, A.P., Nieman, F.H.M., Walenkamp, G.H.I.M., Comparison of Foot Orthoses Made by Podiatrists, Pedorthists and Orthotists regarding Plantar Pressure Reduction in The Netherlands, BMC Musculoskelet Disord, 2005, 6,61 .
37. Bus, S.A., Haspels, R., Busch-Westbroek, T.E., Evaluation and Optimization of Therapeutic Footwear for Neuropathic Diabetic Foot Patients Using In-Shoe Plantar Pressure Analysis, Diabetes Care, 2011, 34, 1595-1600.

38. ISPO, Report of the European Conference for Education in Prosthetics and Orthotics, Conference Proceedings, Dortmund, Germany, 20-39, April 2004, www.ispoint.org.

39. Prescription Custom Foot Orthoses Practice Guidelines, American College of Foot \& Ankle Orthopedics \& Medicine (ACFAOM), 2006.

40. Therapeutic Shoes or Inserts, The Official U.S. Government Site for Medicare - Medicare. gov, https://www.medicare.gov/coverage/ therapeutic-shoes-or-inserts.html.

(C) 2017 by the author(s). Published by INCDTPICPI, Bucharest, RO. This is an open access article distributed under the terms and conditions of the Creative Commons Attribution license (http:// creativecommons.org/licenses/by/4.0/). 